\begin{tabular}{l|cc}
\hline DE & $\begin{array}{c}\text { DE GRUYTER } \\
\text { OPEN }\end{array}$ & ECONOMIC THEMES (2016) 54(1): 45-60 \\
\hline
\end{tabular}

\title{
PRIVATISATION AND INVESTMENT ACTIVITY IN THE TOURISM OF THE REPUBLIC OF SERBIA
}

\author{
Živorad Gligorijević \\ University of Niš, Faculty of Economics, Serbia \\ $\bowtie$ zivorad.gligorijevic@eknfak.ni.ac.rs \\ Predrag Ubavić \\ „Planinka“Ltd., Kuršumlija, Serbia \\ $\bowtie$ p.ubavic@gmail.com; predrag.ubavic@prolomvoda.com
}

UDC

338.246 .02

5.88:338.48

(497.11)

Review

paper

Received:

14.09.2015

Accepted:

23.03.2016

\begin{abstract}
As other countries of Central and Southeastern Europe, the Republic of Serbia at the end of the 20th and the beginning of the 21 st century entered the process of universal transformation, which in essence represented a powerful political and economic movement for thorough changes in all parts of social and economic life. The central place in total transformational processes was taken by property, that is ownership transformation. The purpose of this research are numerous changes and the effects caused by the ownership transformation, that is privatisation in all economic activities, and in tourism as well. The research methods used in this paper are: analysis method, synthesis method, abstraction method, generalisation method, comparison method, as well as mathematical and statistical methods. The research results show that the effects of the privatisation in the tourism activities of Serbia are rather devastating. Besides, there were no necessary changes in other elements of business transformation (organisational, managerial, personnel, technological and other), what is the decrease in quality of tourist offer in Serbia and its bad position on the international tourism market. Taking into account that the Republic of Serbia has included the development of tourism amongst the priorities of its actual economic policy and development strategy, results of this research should by its originality, scientific approach to the subject of the research, quality and expertise, complete research material in this scientific field, also to point out new possibilities of Serbian tourism development to creators of economic, touristic and investment politics.
\end{abstract}

Key words: Serbian tourism, privatisation, effects of privatisation, investments, sources of investments.

JEL classification: R11, Z32, E22 


\section{Introduction}

The last decade of the previous $\left(20^{\text {th }}\right)$ and the beginning of this $\left(21^{\text {st }}\right)$ century are characterised by major changes among which, surely the most significant one, is the transfer non-market economies into market conditions of economic activity.

The aforesaid changes affected both the developed and less developed countries, which were known as transition. In addition to that, one of the most important segments of universal process of transition presented the business transformation whose basic objectives were: establishing market economy, a reform of property relations, general liberalisation of economic activities conditions, as well as building more effective economic system. That means that business transformation represented extremely complex process, that is the process which assumed, first of all, property transformation (privatisation), then organizational, managing, technological, financial, personnel and other transformation.

As a key element business transformation is considered to be privatisation which, in its own essence, represents a process od partial or complete transfer of social and national into private property, with or without reimbursement, on condition determined by law. The final objective of privatisation was a dominant participation of the private sector in the creation of social product. Thereby, it is necessary to specify that privatisation shouldn't have been its own goal, but means of building institutions and mechanisms of market economy.

During the last two and a half decades privatisation was carried out in Serbia, more or less successfully, in all economic activities, as well in tourism as one of the most significant activities in the tertiary sector. Unfortunately, as well in other countries, which went through transitional changes, the experience of our country also showed numerous deficiencies and absurdities in carrying out the process of privatisation.

Deciding for tourism development, as one of strategic activities in its future economic development, Serbia faces with the lack of capital, infrastructure, knowledge, as well as approach to global marketing and distribution channels, what makes harder a faster and more successful development of this economic activity.

Starting with the fact that the Republic of Serbia has modest possibilities for a financial support in tourism development, there is a need to find foreign sources of finances for this economic activity. In order to obtain successful and continuous tourism development in Serbia, it is necessary for it to become an attractive destination for foreign tourists arrival and, what is more important, foreign investors. Therefore, Serbia needs crucial capital investments in tourism, so it is of utmost importance its successful representation in the international touristic and investment market, as a touristic destination with appropriate investment climate. 


\section{Characteristics of the Privatisation Process in Serbia}

Transitional changes in Serbia, and at the same time property transformation, started in the second half of $1980 \mathrm{~s}$ in the $20^{\text {th }}$ century, by regulations of the former federal state (SFRY). By enacting Law on Right to Time Sharing of Touristic Objects (Time Sharing) from 1986 and Law on Social Capital from 1989, first steps were made towards the creation of conditions for market business and corporative economic management. However, the started process of property transformation slowed down, first of all due to the various phenomena of noneconomic character (general social crises, the secession of Slovenia and Croatia, disintegration of the common state - SFRY, breaking out of war conflicts, a great number of refugees and exiles, including other known happenings).

In Serbia, in the middle of 1991, the Law on Conditions and Procedure of Transformation Social Property into Other Forms of Property was declared, by which the following models of privatisation were predicted and developed: (1) issue and sale of shares in order to sell social capital; (2) issue of shares in order to increase the capital; (3) saleof the company or its part; (4) lease and (5) concluding an agreement onmanaging company's business (Ubavić, 2014, p. 65).

Due to culmination of hyperinflation (during 1993) in Serbia in 1994 the Law on Revalorisation of Social Capital was adopted, by which the process of property transformation was stopped. Coming into force, the aforesaid Law made some companies cancel their already begun processes of privatisation, while other companies continued with paying off shares. During that period a lot of trial disputes also occured considering property and estimation of companies' value.

Hotel and catering companies were among the first companies which started the process of property transformation (Barjaktarović \& Barjaktarović, 2011). During the period from the middle of August 1990 until the end of April 1994 property transformation included $69,9 \%$ of Serbia, that is 2.572 social enterprises. Within that process Vojvodina surpassed (in which was involved $81,7 \%$ of social enterprises), then Central Serbia (where transformation included $61,7 \%$ of social enterprises), whereas the process of transformation on Kosovo and Metohia included 253 enterprises (along with a significant impact of the state). As for economic activities, property transformation mostly included industry (with approximatelly $4 / 5$ enterprises) and hotel-keeping with over 72\% enterprises (Marsenić, 1996, pp. 475-476).

Law on Property Transformation was made in 1997. One of the basic regulations of this Law referred to a free shares distribution to employees, the previously employed workers and retired persons in the amount of not more than $60 \%$ of the social capital's value. The aforesaid Law also regulated that $30 \%$ of social capital's value can be paid off by the interested buyers within the time period up to 6 years, whereas $10 \%$ of the social capital transferred to the 
Fund for Pension and Disability Insurance, and in the case of any surplus capital after shares register would be transferred into property of the State Stock Fund.

A model of privatisation which was based on the mentioned Law was not compulsory and without a fixed term deposit, which means that the managing organs at enterprises decides whether they will go into privatisation or not. Being under a big pressure of self-managing and union structures, managing organs at enterprises did not feel a necessity to make changes and decided to leave it to the nature of events, what caused social enterprise's capital to be transferred into private companies through different and suspicious business transactions and without any control.

Law on property transformation from 1997 created a condition to start the process of privatisation in more than 1.000 enterprises in Serbia, of which 12 enterprises were from the field of hotel keeping and catering. As a key element, during the sale of these enterprises, appeared the share price paid by the majority owner and social programme, whereas investment programme was secondary matter.

After October changes in 2000 in Serbia both political and economic atmosphere in which its economy functioned also changed. Namely, the previous approach to privatisation was modified, therefore at the end of June 2001 there was a new Law on Privatisation into force. The aforesaid Law predicted privatisation of the total social capital of enterprises all at once, where the majority package of shares was sold to one owner or small number of owners. The surplus of working force was solved by a social programme which was financied from the budget and it predicted obligatory investment into privatised enterprisea. A model of privatisation based on this Law was centralised, because the whole procedure was carried out by the state, i.e. Agency for Privatisation. the majority part of social capital of the enterprise was sold to one buyer or a consorcium (from minimal 51\% to maximum $70 \%$ ), while $30 \%$ of the social capital of the enterprise (which were privatised by auction) was distributed free of charge to employees and the previous workers of the enterprise, that is at the enterprises which were privatised by tenders $15 \%$ of social capital was distributed free of charge.

The key state institution which dealt with privatisation in accordance with the Law on Privatisation from 2001 was the Agency for Privatisation. In accordance with the aforesaid Law two more state subjects authorised to carry out the process of privatisation were predicted, and those are Stock Fund and Central register for securities.

Starting with two basic models of the sale of social, that is state capital by: (1) a public tender and (2) public auction, can be concluded that bid privatisations were intended foe such enterprises which were of strategic significance for Serbia. At the beginning of $21^{\text {st }}$ century in Serbia was about 150 enterprises which were required to be privatized by a public tender, while other enterprises (about 4.000 of them) should have been privatized by public 
auctions. As the main criteria for selection of the best purchaser in public tenders were considered: (1) the amount of selling price; (2) the amount of investment programme; (3) the amount of social programme and (4) the quality of programme to protect environment (Djordjević, 2009, p. 31).

The funds granted for the privatisation of social and state enterprises should have been used to finance the following causes: (1) Republic fund authorised for pension and disability insurance of the employed in the amount of $10 \%$ of the seliing price; (2) incentive development; (3) paying reimbursement to persons whose property was nationalised in the amount of $5 \%$ of the selling price; (4) returning debts whose guarantor is the Republic of Serbia; (5) sale expenses within the process of privatisation; (6) special programme of economy development and environment protection which is made by an authority of teritorial autonomy, that is the local self-management $(5 \%$ for the territorial autonomy and 5\% for the local self-management) and (7) other purposes (Law on Privatisation, 2001).

The control of the whole privatisation process in the Republic of Serbia, during the first decade of the 21 st century, was handled by a strictly formalised principle of vertical responsibility. Institutions for carrying out the Law on Privatisation responded to the executive authority (The Government of the Republic of Serbia), whereas the executive authority organs responded to the National Parlament of the Republic of Serbia. Therefore, within the process of privatisation in the Republic of Serbia active roles took both executive and legislative authority, and in individual moments a role of court authority also stood out (for example, in case of numerous and various court disputes related to the process of privatisation).

Just like in many other countries which went through transitional changes different negative phenomena also manifested in Serbia during this process, and also afterwards. First of all, a gross of social product decreased, export decreased, living standard of Serbian citizens worsened, the number of unemployed increased, the number of various criminal acts increased as well, different forms of deviant behaviour appeared, etc. However, it should be pointed out that it is very hard to give one general estimation of effects, of the process of privatisation carried out so far in the Republic of Serbia. For some more precise and more expert evaluations it is necessary to pass a time period long enough in order to build all required institutions of market economy and private property to show its real character.

\section{Analysis of the Effects of Privatisation in Tourism Activity in Serbia}

As one of the most important activity within the tertiar sector of economy, tourism among the first entered the transitional changes. The majority of enterprises in touristim activity was, due to their value, privatised by auction, 
whereas incomparably fewer number of enterprises was privatised by a public tender. As in other activities, also in tourism, privatisation did not always give expected results. Amongst new owners and employees from privatised enterprises often occured different disputes which were solved at a court.

According to the information of the Agency for Privatisation from hotelkeeping and catering activity about 150 enterprises were privatised, which is approximatelly $70 \%$ of the total number of enterprises in this field. However, almost every fifth agreement on privatisation is cancelled due to unperformed contracted obligations by the new owners, whereas for a certain number of enterprises restructuring was suggested. The total amount of funds based on sale of the enterprises in this field was about 500 millions of euros, what is far below expectations, both the state and employees in this field. The biggest influx was achieved by selling the hotel „Continental " for 148,8 millions of euros, then the touristic enterprise TP „Putnik" for 44 millions of euros (the second time), hotel ,, Yugoslavia “ for 31,1 millions of euros and the hotel ,, Metropol “ for 23,7 millions of euros (Barjaktarović \& Barjaktarović, 2011, p. 343).

Privatisation that was carried out in hotel-keeping and catering activity opened numerous issues and dillemas, and the most frequent issues in this process were the following: (1) in most privatized enterprises, except the change of the owner, there were no changes in any other element of the business transformation, what negatively affected the quality of the provided services and their competition position; (2) unexpectingly small financial effects from privatisation affected the small influx of means in the republic budget and great discontent of the employed, and at the same time in a great deal there was no interes of foreign partners for these enterprises purchase; (3) some enterprises or their parts for a very short time changed several owners, whish shows in the best way the motives of their purchase; (4) just a small number of privatised enterprises were governed by professional managers, whereas most of these enterprises met frequent changes of managers, which negatively affected their image, the employed and total business; (5) due to bad control of the whole process of privatisation a great number of new owners did not completely obeyed taken obligations to their investment and social prigrammes; (6) certain number of enterprises was not privatised even after more held auctions, therefore the Government's recommendation is for them to be restructured.

As opposed to numerous examples of bad effects of privatisation in hotelkeeping activity, there is a small number of these enterprises, which successfully went through this process and can be a role model for all those enterprises, which did not start the process of property and total business transformation. As good examples of successful business transformation and privatisation can be: the hotel "Mona" on the mountain Zlatibor, the hotel "Vojvodina " in Zrenjanin, the hotel ,Park" in Novi Sad, the hotel ,Izvor" in Arandjelovac and others (Barjaktarović \& Barjaktarović, 2011, p. 345). 
A general conclusion is that the results of so far process of business transformation, and especially privatisation as its key element, in tourism activity of Serbia rather devastating. This is illustrated best if we take into consideration a big number of redundant staff, a lot of closed enterprises, a big number of cancelled agreements on privatisation, as well as a number of unprivatised enterprises. Non existance of strategic approach to privatisation, disregard for specificity of tourism activity, as well as lack of will, knowledge and capability, not only in the state, but in managerial structures (in privatized enterprises) to carry out essential changes in business caused these and such results. Due to the fact that the main motive of purchase for most new owners of tourism enterprises, hotels and other objects was that these objects should be sold as soon as possible at higher prices or, because of the appropriate location on this they were situated, change their purpose. Lack of interest by the state to check the origin of the capital by which these objects (privatised) enterprises were purchased caused the ideal possibilities for money laundry of suspicious origin.

On the other hand, enterprises which were not privatised were not interested for some serious investments and introducing some essential changes in business, which affected very badly the quality of tourism offer and their competition position in the market.

Therefore, privatisation in tourism activities in Serbia did not show the expected results. Besides, in most cases, there were no necessary changes in other elements of business transformation (organisational, managerial, technological, personnel, financial and other), which caused a low quality of our touristic products /services and bad position of tourism offer of Serbia in the international and regional touristic market. In order to get over the existing problems it is necessary, first of all, to improve legislative regulation in this field, to hire professional managers with international experience, also to permanently work on the education of all levels of managers and employees.

\section{Investments in the Tourism of Serbia}

Countries in transition, and amongst them Serbia, face numerous issues while carrying out economic reforms which are directed to find out foreign sources of financing, so that they try to come out from the occured problems. In that way, foreign investments become crucial factor in economic development of transitional countries and contribute to improvement of their competitivness on the international market.

Although the Republic of Serbia included the tourism activity in its developing priorities, Serbia is still not recognised as a destination on the world touristic map, and its tourism owns only comparative but not competitive advantages.

Presently unenviable position of tourism in Serbia shows a necessity of urgent state financial support to this economic activity in the form of various 
subventions, tax incentives, affordable credits and other instruments of financial assistance. However, for a long-term and more stable development of tourism in Serbia, beside financial support of the state, also are required capital investments as an instrument of its healthy development, and because of that, they should be priorities.

Investments in tourism represent a part of economic investments. In theory and also in practice often prevails completely wrong understanding that investmnet in tourism is in fact investmenst in restaurant management. However, although restaurant management has a huge influence on tourism development we cannot neglect other elements of tourism offer (traffic, trade, crafts, tourist agencies and others), which also have a great impact on the development of tourism, and exactly for that reason investments in tourism should be considered in one wider context (Unković \& Zečević, 2011, p. 375). Namely, in defining investments in tourism, it is necessary to include all investments in extensive and intensive development of restaurant management, traffic, trade, crafts, tourist agencies and other activities that make the tourism economy, to the extent in which they are included in direct and indirect providing for tourists' needs. Aside from the aforesaid, investment in tourism is also investment in permanent working assets, which are required for normal functioning of the tourism economy (Unković \& Zečević, 2011).

As a special issue, in the majority of touristically developed countries in the world, there is a statistical monitoring of investments in tourism. In many countries, only means invested in restaurant management and economic subjects in the field of tourism statistically are monitored. In our country, the official statistics had up to 1965 expressed investments in restaurant management and tourism together with trade, and only later they were expressed separately.

Due to the general economic situation, the Republic of Serbia could not during the previous period support more significantly the development of its tourism. If we analyse the first decade of $21^{\text {st }}$ century we can clearly notice a modest financial support expressed, first of all, in the way of subvention and affordable credits. As the main grantor of subvention was a resource of the ministry responsible for tourism, while affordable credits were approved by the Ministry of Finance and Economy. The best example of affordable credits for development of tourism are those credits which were approved to our citizens for trips in Serbia with an annual interest rate of 7,5\% and time limit for payment of 3 year. Aside from the modest amounts with which was supported the development of tourism in Serbia, (1,56 billions of RSD) only relative participation of tourism significantly stayed behind relative participation of other activities in state assistance within the observed period, which was from 0,8\% to 5,2\% (Leković \& Pantić, 2014, pp. 66-67). 
We are all withesses of general globalisation and extremely dynamic movements of international capital. On the other hand, taking into consideration that the Republic of Serbia is a developing country (with a little more population than 7 million), also that its process of transition still has has not been fully completed, it is evident that by relying only on its own sources Serbia cannot achieve some more significant results in its tourism and general economic developlment. Because of that there is a conclusion on the necessity to obtain foreign sources of financies, first of all, foreign direct investments, ${ }^{1}$ not only in tourism, but in other economic activities. Or else, foreign direct investments can be realised in different ways as, for instance, are: greenfield and brownfield investments, mutual investments, international mergers and acquisitions (Grbić \& Janković, 2014, p. 62).

Some researches of UNCTAD (United Nations Conference on Trade and Development) show that, from a global level, foreign direct investments in tourism are relatively small, compared to other activities. Tourism participates with only $1 \%$ to $2 \%$ in total output FDI stocks from the biggest home countries, while its participation in total input FDI stocks, in the biggest host countries, was even less (Bošković, 2008, p. 25). However, during the last decade of $20^{\text {th }}$ and the beginning of $21^{\text {st }}$ century, a sudden growth of investments was registered in service sector. Such growth of attracting investments in service sector was affected by numerous factors, and as the most important are the following: (1) fast growth of demand for services; (2) growth of awareness on significance of services in order to achieve efficient and productive production in all sectors and (3) liberalisation of investment politics in the service sector in many countries (Popovčić-Avrić \& Djenić, 2011).

The most important countries, sources of foreign direct investments output in tourism, are from the group of developed countries, first of all, The United States of America, Great Britain, France and Canada. However, during the past several years, increase of FDI is being registered by multinational companies from Singapore, Hong Kong, The United Arab Emirates, Cuba, Malesia, Poland, South African Republic and Mauritius. Investors from the aforesaid countries can represent extremely significant source of new investments, capital and skills for the least touristically developed countries.

Experiences of the countries which used foreign direct investments in tourism are different and not only positive, but negative as well. The effects of influx of these investments in the host countries are mostly expressed through demand, capital, technology, obtaining skills, human resources, local firms, balance of payments, environment protection, etc. Some critics of foreign direct investments warn that in this way, after five to six years from the moment of

\footnotetext{
${ }^{1}$ It is necessary to point out that foreign direct investments (FDI) do not include only immediate investment of capital, but the transfer of new technologies, new approach to the market, implementation of new managerial and organizational knowledge, etc.
} 
investment, comes to the withdrawal of money from the host country. Namely, some multinational companies, while importing raw materials, increase the prices and in that way withdraw capital from the host country into the home country. As the consequence of all the mentioned, a host country has a lower profit and pays less tax, so that a part of foreign currency goes abroad without being controled by anyone. For the aforesaid reasons there is a huge liability in the governments of the host countries because they are forced to make decisions carefully regarding development of tourism, especially if they wish to base that development on a higher influx of foreign direct investments.

As for influx of foreign direct investments in Serbia, from the point of view of the world scales, it can be said that it is still irrelevant. Namely, up to 2008 the total amount of foreign direct investments placed in Serbia, was only $0,0011 \%$ of total FDI in the world. Even within the regional frames, Serbia also did not manage to become more significant destination for attracting foreign capital. In that way, for instance, in 2008 the total influx of foreign direct investments in Serbia was $0,018 \%$ of the total amount of all such investments in the countries of Central and Eastern Europe (Grbić, Janković, 2014, p. 64).

Table 1 Influx of foreign direct investments in Serbia from 2000 to 2013 (in millions of USD)

\begin{tabular}{||c|c|c|c||}
\hline YEAR & INFLUX OF FDI & YEAR & INFLUX OF FDI \\
\hline 2000. & 11 & 2007. & 3439 \\
\hline 2001. & 35 & 2008. & 2955 \\
\hline 2002. & 326 & 2009. & 1959 \\
\hline 2003. & 1071 & 2010. & 1329 \\
\hline 2004. & 796 & 2011. & 2709 \\
\hline 2005. & 1577 & 2012. & 352 \\
\hline 2006. & 4256 & 2013. & 1034 \\
\hline
\end{tabular}

Source: UNCTAD, 2011, World Investment Report 2011, New York and Geneva, p. 190.; UNCTAD, 2012, World Investment Report 2012, New York and Geneva, p. 172.; www.nbs.rs/internet/cirilica/80/platni_bilans.html; http://bif.rs/2013/08/sdi-srbija-najgorerangirana-u-poslednjih-12-godina; http://bif.rs/2014/07/sta-pokazuje-analiza-priliva-stranihdirektnih-investicija-u-srbiji.

At the beginning of $21^{\text {st }}$ century in Serbia, from year to year, there is an oscillation in influx of foreign direct investments. The biggest influx of foreign direct investments in Serbia was recorded based on privatisation. In that way, for instance a record influx of foreign direct investments was registered in 2006 first of all due to the sale of ,Mobtel", ,Hemofarm “, , Vojvođanska bank", ,Panonska bank“, etc.

The highest amounts, based on foreign direct investments, in the economy of Serbia were placed by investors from the countries of the European Union and the regional countries (Central and Eastern Europe), as some individual remote countries 
(The United States of America, Russia, Japan and Israel), whereby the significance of these countries differs in some years (Jovanović-Stojadinović, 2013, p. 48).

If sector structure of foreign direct investments in Serbia is analysed, within the period from 2000 until 2013, one can notice a participation of some economic sectors, as well some economic activities within them, by some years. In that way, for example, during 2013 there were a lot of investments in the service sector (service of accommodation and food) $23 \%$, then in agriculture production $21 \%$, water supply $16 \%$, civil engineering $9 \%$, mining $8 \%$, trade activity $7 \%$, electrical power and gas supply $2 \%$, while manufacture industry, traffic, information and communication had only $1 \%$ of participation. We should also point out that European companies made nearly $90 \%$ of all foreign investors in that year (Grandov et al., 2014, pp. 152-153).

In order to make Serbia more attractive investing destination it is necessary, first of all, to establish a political and macroeconomic stability in the country. During the past 10-15 years in Serbia were carried out different social, political and economic reforms, in order to speed up the process of its accesion to the European Union. In April 2008 was signed an Agreement on stabilization and accesion by which Serbia took over an obligation to establish a zone of free trade and adjust its legislation with the legislation of the European Union. This Agreement came into force in September 2013, and the same year Serbia gained $a$ candidate status for the membership in the European Union. For foreign investors it is very important the fact that since 2000 Serbia has had a signed Agreement on free trade with Russia. Similar agreements are signed with Belorussia and Turkey in 2009, as well with Kazahstan in 2010. Foreign trade exchange with The United States of America, in a great deal, is regulated by a General system of preferential (approved in July 2005). However, the main trade and investing partner of Serbia is for the time being The European Union, so development of intensive economic coopeartion and strengthening mutual relationships with the European Union is of crucial importance for Serbia (Grandov et al., 2014).

Due to the fact that foreign investors are very demanding, for their investments there must be created a very favorable investing climate, which means a sequence of tax benefits, stimulative measures, protection from birocratic arrogance and corruption, and similar. The host country especially should enable different tax incentives such as, for instance, low tax rates on the added value (VAT), tax on enterprize's profit, tax on income, etc. ${ }^{2}$

Investing in a certain country is often motivated by low incomes, coresponding employment politics, as well as low expenses of making workers redundant. Although salaries in Serbia are amongst the lowest in Europe, investors, consider that work is expensive in real practice due to the various fiscal burdens (taxes and contributions for incomes).

\footnotetext{
${ }^{2}$ Rates of the mentioned taxes are, today in Serbia amongst the lowest in the region (rate of VAT $20 \%$, tax rate on enterprize's income $10 \%$, and tax on income $12 \%$ ).
} 
So far, the experience showed that application only of tax incentives is not enough to attract foreign investors, but that they should stand out only after an adequate investing climate is created and when various non-tax incentives are applied in the host country. Refering to this, also the financial support as granting free funds, fast registration of economic subjects and minimal administrative obstacles are very important in case of building and opening business objects.

More serious investments by foreign investors in Serbia are prevented by insufficiently developed infrastructure, bad legistration, lack of liquidity, as well as intransparancy of the market. Difficulties which occur during application and projects planning and unpredictability of the market represent the biggest issue for foreign investors. In the existing conditions, institutionalised investors are more interested in short-term investments of low risk.

In many experts' opinions, the key of the success which should obtain the fundamental trust of foreign investors to invest in Serbia is its accession into the European Union, as well as previous adaptation to legislative and regulative frame in order to form a more secured and more transparent market (http://www.turistickisvet-hotnews.com/vest/sta-koci-investicije-u-srbiji).

To attract various categories of investors it is necessary to direct the campaign, that is, the privatisation of presentation of investing projects to target groups of investors. The real target groups of investors that Serbia should observe are: (1) domestic investors; (2) foreign investors and (3) diaspora (our people who live abroad). Investors decide for investing in certain destination according to its reputation, appearance, good impression, image, and similar. Regarding this, the role of local self-management units is very important in preparing investing projects, and in certain cases they themselves should invest in certain projects, in accordance with their potentials. In that way, a good starting base to attract bigger and more serious investors can be created (http://turizam-u-srbiji.blogspot.com/2013/12/investicije-u-turizam-kreiranje.html).

As an example of a successful cooperation between investors and local selfmanagement unit is investment in building and putting in order Srebro lake near Veliko Gradiste. By coming of „NCA Investment Group “ from Belgrade into the grandious project "Srebro Lake resort" the image was changed radically, as well the contents and popularity of Srebro lake, one of exclusive natural jewels in the northeast of Serbia. Realization of this ambitious project opened a new chapter in tourism development in Serbia because with it Srebro lake started to get a new shape, folloowing the principle „old destination in completely new image" (http://www.nirapress.com/content/view/1951/2).

Successful investing ventures which have been realized during the several past years into tourism of Serbia, first of all include a multimillion investments 
in hotel-keeping, not only in Belgrade, but in other parts of Serbia. ${ }^{3}$ In that way, many and various tourism programmes were activated such as: sports centres, congress centres, ski centres, spa and wellness centres, aqua parks, horse farms, vinaries and others, what will surely contribute significantly to improvement of touristic offer in Serbia in the future.

Except investment in providing service of accommodation and food, for a successful and long-term tourism development in Serbia is necessary to have investments and other activities which are complementary with tourism development and with it, on specific space and make a unique whole. In this case, first of all, is thiught of traffic, trade, civil engineering, some branches of industry, agriculture, productive crafts and other activities. For a stable and continuous tourism development in Serbia, it is also of utmost importance to form adequate tourism clusters. Thereby, each tourism cluster should develop those aspects of tourism and those tourism products/services for which has the best potentials. However, one must take into consideration that tourism clusters do not represent competition to one another so that they will develop the same touristic products/services.

\section{Conclusion}

Transitional changes in Serbia were started at the end of the $1980 \mathrm{~s}$ of the $20^{\text {th }}$ century. However, aside from that, the process lasts much longer than in other countries of Central and Southeastern Europe. In that process, one of the most important segments of transition was business transformation. Basic golas of business transformation were: a reform of property relations, general liberalization of economic activity 's conditions, establishing a market economy and building more efficient economic system. As a complex process, business transformation meant, first of all, property transformation, i.e. privatisation, and then organizational, managerial, technological, personnel, financial and other transformation.

Similarly in other countries which went through transition, in Serbia also showed numerous omissions and anomalies while carrying out the process of privatisation. The aforesaid circumstances resulted in the decrease in social gross product, decreasing living standard of citizens, increasing the number of the unemployed, general crises in the country, appearing various forms of deviant behaviour, etc.

\footnotetext{
${ }^{3}$ Austrian ,Falkensteiner “ (,Falkensteiner Michaeler Tourism Group AG“-FMTG) opened at the end of 2012 a hotel in Belgrade (Novi Beograd) in which it invested about 45 million EUR. This famous Austrian hotel chain took over the management of the hotel on Old mountain for the period of 15 years. By the scope of the investments the following hotels are worth mentioning: ,Crowne Plaza " as a part of the hotel chain „Inter Continental Hotels Group“, „Holiday Inn“ and „Metropol“ in Belgrade, then the hotel „Izvor" in Arandjelovac (in which ,Alco Group “ invested about 35 million EUR, and then more 7 million EUR in aqua park), the hotel „Premier Aqua “ in Vrdnik Spa, tourist-sports centre at Pasina cesma near Leskovac (investor „Emirates Power"), aqua park „Petroland" in Backi Petrovac (in which Slovakian company "Aqua Therm Invest" invested about 8,5 million EUR), etc. (http://www.ekapija.com/website/sr/page/680851/RETROSPEKTIVA-2012-Investicije-u-oblasti-
}

TURIZMA-ZABAVE-I-REKREACIJE-koje-su-izazvale-najvece-interesovanje-korisnika-eKapije). 
The destiny of the total economy in Serbia, which went through the transition, reflected the destiny of tourism activity as well. By numerous evaluations the results of the process of business transformation so far, especially privatisation, in tourism activity of Serbia are pretty devastating. Those results manifested, first of all, through plenty of closed enterprises and workers made redundant, as well a lot of cancelled agreements on privatisation. The epilogue of everything said is the decrease in the quality of the tourism offer in Serbia and its bad position in the international tourism market.

Because it still a little known destination on the world tourism map Serbia must, aside from own financial support, intensively work on providing capital investments for long-term and stable development of its tourism. In this regard, a special importance in tourism development in Serbia should have foreign direct investments, which do not include only immediate investing a certain amount of capital but, on the contrary, should include transfer of new technologies, implementation of managerial and organizational knowledge, a new approach to market, etc.

Due to the fact that tourism is heterogeneous, aside from investment in the service of accommodation and food, the investments in its complementary activities are also necessary, which makes a unified whole on the specific space. Accordingly, a role of a local self-management unit should stand out, which will provide basic infrastructure, as well as a favorable atmosphere for the activity of potential investors.

In order to attract more crucial foreign investors it is necessary, first of all, to establish political, legislative and macroeconomical stability in the country, also permanently to work on creating favourable investing climate within it. Approach to this issue must be interdisciplinary and different profile experts must work on it (economists, layers, financial experts, marketing specialists, planners in tourism, researchers in touristic market and trends, space planners, urban planners, architects, graphic designers, artists, sociologists and others).

The ultimate goal in investing ventures in tourism should be the creation of extraordinary attractive, inovative and business successful investing projects which will enable investors high incomes and financial security, and future tourists' unique experience.

\section{References}

Barjaktarović, D. \& Barjaktarović, L. (2011). Transformacija hotelsko-ugostiteljske privrede Srbije ispod očekivanja. 8. Naučni skup sa međunarodnim učešćem Sinergija 2011, Bijeljina: Univerzitet Sinergija, str. 340-346. Retreived: www.singipedia.singidunum.ac.rs/content/2544-Transformacija-hotelskougostiteljske-privrede-Srbije-ispod-očekivanja, accessed: 07.09.2015. 
Biznis i finansije (2013). Srbija najgore rangirana u poslednjih 12 godina. Retreived:: http://bif.rs/2013/08/sdi-srbija-najgore-rangirana-u-poslednjih-12-godina, pristupljeno: 31.08.2015.

Biznis i finansije (2014). Šta pokazuje analiza priliva stranih direktnih investicija u Srbiji? Retreived: http://bif.rs/2014/07/sta-pokazuje-analiza-priliva-stranihdirektnih-investicija-u-srbiji, accessed: 31.08.2015.

Bošković, T. (2008). Strane direktne investicije u turizmu kao faktor razvoja. Škola biznisa, 3, 23-27.

Đorđević, M. (2009). Proces privatizacije u Srbiji u periodu od 2000. do 2008. godine. Škola biznisa, 2, 29-34.

Ekapija (2013). Retrospektiva 2012 - Investicije u oblasti turizma, zabave i rekreacije koje su izazvale najveće interesovanje korisnika "eKapije". Retreived: http://www.ekapija.com/website/sr/page/680851/RETROSPEKTIVA-2012Investicije-u-oblasti-TURIZMA-ZABAVE-I-REKREACIJE-koje-su-izazvalenajvece-interesovanje-korisnika-eKapije, accessed: 27.03.2015.

Grandov, Z., Stankov, B. \& Roganović, M. (2014). Uporedna analiza faktora koji podstiču inostrane investitore na direktna ulaganja u Srbiji i Rumuniji. Škola biznisa, 2, 141-169, doi: 10.5937/skolbiz2-7420.

Grbić, M. \& Janković N. (2014). Priliv i sektorska struktura grinfild i braunfild investicija u lokalnoj privredi. U: Maksimović Lj. i Stanišić N. (ured.) Stanje $i$ perspektive ekonomskog razvoja grada Kragujevca (str. 61-71). Kragujevac: Ekonomski fakultet. Retreived: www.ekfak.kg.ac.rs/en/node/1454, accessed: 25.06. 2015.

Jovanović-Stojadinović, S. (2013). Strane direktne investicije kao oblik finansiranja globalne ekonomije. Bankarstvo, 42 (1), 34-57.

Leković, M. \& Pantić, N. (2014). Državna finansijska podrška i kapitalne investicije kao faktori razvoja srpskog turizma. Menadžment u hotelijerstvu i turizmu, 2 (1), 65-70.

Marsenić, D. (1996). Ekonomika Jugoslavije. Beograd: Ekonomski fakultet.

Narodna banka Srbije. Retreived: http://www.nbs.rs/internet/cirilica/80/platni_bilans.html pristupljeno: 19.07.2012.

Nira press. Preuzeto sa: http://www.nirapress.com/content/view/1951/2/, pristupljeno: 27.03.2015.

Popovčić-Avrić, S. \& Đenić, M. (2011). Strane direktne investicije kao dinamički faktor svetske privrede. Singidunum revija, 8 (1), 197-206.

Turistički cvet. Retreived: http://www.turistickisvet-hotnews.com/vesti/sta-kociinvesticije-u-srbiji/, accessed: 27.03.2015.

Turizam u Srbiji (2013). Investicije u turizam - kreiranje projekata i njihova prezentacija. Retreived: http://turizam-u-srbiji.blogspot.com/2013/12/ investicije-u-turizamkreiranje.html, accessed: 27.03.2015.

Ubavić, P. (2014). Strategijske osnove i pravci razvoja turizma na teritoriji Republike Srbije, doktorska disertacija. Niš: Ekonomski fakultet.

UNCTAD (2011). World Investment Report 2011. New York and Geneva: United Nations.

UNCTAD (2012). World Investment Report 2012. New York and Geneva: United Nations.

Unković, S. \& Zečević, B. (2011). Ekonomika turizma, 22. izdanje. Beograd: Centar za izdavačku delatnost Ekonomskog fakulteta u Beogradu. 
Zakon o privatizaciji (2001). (Law on privatisation, 2001) Službeni glasnik Republike Srbije, 38/2001 i 18/2003, Beograd.

\title{
PRIVATIZACIJA I INVESTICIONA AKTIVNOST U TURIZMU REPUBLIKE SRBIJE
}

\begin{abstract}
Apstrakt: Kao i druge zemlje Centralne i Jugoistočne Evrope, Republika Srbija je krajem XX i početkom XXI veka ušla u proces sveobuhvatne transformacije, koja je u suštini predstavljala snažan politički i ekonomski pokret za korenitim promenama u svim sferama društvenog i privrednog života. Centralno mesto u ukupnim transformacionim procesima zauzimala je svojinska, odnosno vlasnička transformacija. Svrha ovog istraživanja su brojne promene i posledice koje je prouzrokovala vlasnička transformacija, to jest privatizacija u svim privrednim delatnostima, a samim tim i u turizmu. Metodi istraživanja korišceni u ovom radu su: metod analize, metod sinteze, metod apstrakcije, metod generalizacije, metod komparacije, kao i matematički i statistički metodi. Rezultati istraživanja pokazuju da su efekti privatizacije u turističkoj delatnosti Srbije, gotovo, poražavajući. Osim toga, izostale su neophodne promene i u ostalim elementima poslovne transformacije (organizacionoj, upravljačkoj, kadrovskoj, tehnološkoj i drugim), što je dovelo do pada kvaliteta turističke ponude Srbije i njene loše pozicije na međunarodnom turističkom tržištu. Imajući u vidu činjenicu da je Republika Srbija razvoj turizma svrstala u prioritete svoje aktuelne ekonomske politike i razvojne strategije, rezultati ovog istraživanja trebalo bi svojom originalnošću, naučnim pristupom predmetu istraživanja, kvalitetom i stručnošću da upotpune istraživačku građu u ovoj naučnoj oblasti, kao i da kreatorima ekonomske, turističke i investicione politike ukažu na nove mogućnosti razvoja turizma u Srbiji.
\end{abstract}

Ključne reči: turizam Srbije, privatizacija, efekti privatizacije, investicije, izvori investicija.

\section{Authors' biographies}

Živorad Gligorijević, PhD, is a Full Professor at Faculty of Economics, University of Niš. He teaches at the undergraduate, master and doctoral studies. He held the postion of Vice-Dean for scientific work (from 1996 to 1998, and the 2003/04 school year.), and the Vice Dean for finance (from 1998 to 2000). Currently is holding the postion of Chief of the Department of National Economy and Finance. He was secretary and member of the editorial board of "Themes", published by the University of Nis, as well as a member of the editorial board of the journal "Economic Themes" published by the Faculty of Economics in Niš. He has published 25 books (textbooks, monographs), as well as over a hundred papers (in national and international journals, in proceedings of international and national scientific meetings, as well as in thematic collections of papers). He is a member of the presidency of the Society of Economists Nisš and a member of the Scientific Society of Economists of Serbia.

Predrag Ubavić, PhD, was born in Blace. He attended primary school in Gornja Draguša, a secondary school of economics in Niš. At the Faculty of Economics graduated in 1989, MA in 2009 and his doctorate in 2014. He works in the ad "Planinka" Kursumlija. He worked as managers in the hospitality Prolom Banja, a purchasing manager, and is now assistant director of sales. He was a member of the Management Board Ltd. "Planinka" Kursumlija (1995 to 1998). Solidly use computers (Word, Excel, Internet ...). He speaks Russian. 